\title{
Giovanna Angeli, Christine de Pizan et le portrait impossible de l'auteur dans son laboratoire
}

\section{Maria Colombo Timelli}

\section{(2) OpenEdition}

1 Journals

\section{Édition électronique}

URL : http://journals.openedition.org/studifrancesi/27267

DOI : 10.4000/studifrancesi.27267

ISSN : 2421-5856

Éditeur

Rosenberg \& Sellier

\section{Édition imprimée}

Date de publication : 31 décembre 2006

Pagination : 581

ISSN : 0039-2944

\section{Référence électronique}

Maria Colombo Timelli, « Giovanna Angeli, Christine de Pizan et le portrait impossible de l'auteur dans son laboratoire », Studi Francesi [En ligne], 150 (L | III) | 2006, mis en ligne le 30 novembre 2015, consulté le 08 novembre 2020. URL : http://journals.openedition.org/studifrancesi/27267 ; DOI : https://doi.org/ 10.4000/studifrancesi.27267

Ce document a été généré automatiquement le 8 novembre 2020.

\section{(c)}

Studi Francesi è distribuita con Licenza Creative Commons Attribuzione - Non commerciale - Non opere derivate 4.0 Internazionale. 


\title{
Giovanna Angeli, Christine de Pizan et le portrait impossible de l'auteur dans son laboratoire
}

\author{
Maria Colombo Timelli
}

\section{RÉFÉRENCE}

GIovanna ANGeli, Christine de Pizan et le portrait impossible de l'auteur dans son laboratoire, in «Toutes choses sont faictes cleres par escripture». Fonctions et figures d'auteurs du Moyen Âge à l'époque contemporaine. Études rassemblées par Virginie MINET-MAHY, Claude THIRY et Tania VAN HEMELRYCK, «Les Lettres Romanes», numéro hors série, 2004, pp. 57-69.

1 L'œuvre poétique de Christine de Pizan est riche d'interventions personnelles qui semblent dévoiler au lecteur tout entière la réalité biographique du poète. Cependant, G. Angeli montre bien où notre connaissance de l'auteur s'arrête: la zone où se fabrique l'écriture, le «laboratoire de l'écrivain» (p. 68), nous reste, malgré tout, inaccessible. 